\title{
水環境に関連する住民活動の実態分析と流域連携に関する考察* \\ Citizen Activity for Preservation of Water Environment and Cooperation in the Basin*
}

\author{
宮本善和 $* * \cdot$ 道上正規 $* * *$ ·喜多秀行 $* * * * \cdot$ 檜谷治 $* * * * *$ \\ By Yoshikazu Miyamoto** $\cdot$ Masanori Michiue ${ }^{* *} \cdot$ Hideyuki Kita ${ }^{* * *} \cdot$ Osamu Hinokidani ${ }^{* * * *}$
}

\section{1.はじめに}

先の全国総合開発計画「21 世紀の国土のグランドデザ イン」では、国土管理の基本的な単位として流域圏を位置 づけ、多様な主体の参加と連携による取組みを推進する ことがうたわれた。また、昨今の河川制度の見直しで、 河川管理に“環境”が内部目的化されるとともに、川づ くりや水環境保全に流域住民の参加と連携を図る試みが 盛んになっている。水環境保全とは従来水質保全と同義 に捉えられてきたが、昨今では水源涵養や雨水利用等の 健全な水循環の回復、生態系保全、水辺景観の保全等、 様々な取組みが必要とされている ${ }^{1)}$ 。そして、これらに 対する参加と連携のアプローチの必要性は、行政サイド だけでなく住民活動サイドからも認識されている2）。

流域を単位に川づくりや水環境保全に流域住民の参加 と連携を促す意義としては、(1)水環境保全に対する意識 向上を促し広域的な対処を可能にする、(2)対話により地 域の実情に応じた川づくりが図れる、(3)川や水を介した 流域のつながりが再構築できる、(4)活動参加を通し地域 コミュニティの活性化が図れる等が考えられ、そのため の方途を見出すことが重要となっている。

一方、水環境に関わる日本の住民活動団体（以下、活 動団体と称す）のほとんどは法人資格を有さず、余暇を 利用した自発的な活動ながらも多彩な活動を展開してい ると推察され、水環境保全における流域連携の担い手と して、住民への参加機会の提供者として注目される。し かし、活動団体相互や他の主体との連携は各地で始まっ たばかりで、様々な連携上の問題点を抱えており、目標 に向けた効果的な連携の方途が求められている。

水環境に関わる活動団体の実態調査としては、平成 6 年度に 179 団体をアンケート調査したものがある ${ }^{3)}$ が、 これは全般的な活動内容の実態把握に至っておらず、ま た多様な活動団体のタイプや活動の傾向を明らかにして いない。他方、流域連携に関する研究としては、流域の 特徵や流程の変化と住民の意識・行動の関連性を分析し たものや4）5，、上下流住民の意識から連携の可能性を探

*キーワーズ : 市民参加、土木施設維持管理、シ人公么分析

**正員、鳥取大学工学研究科博士後期課程、中央開発(侏)事 業推進本部技術開発部（東京都新宿区西早稲田 3-13-5、 TEL03-3208-9913、FAX03-3208-9915)

***7工口-、工博、鳥取大学工学部土木工学科（鳥取市湖山町 南 4-101、TEL0857-31-5282、FAX0857-28-7899)

****正員、工博、鳥取大学工学部社会開発㳄公工学科 (鳥取市 湖山町南 4-101、TEL0857-31-5309、FAX0857-31-0882)

***** 正員、工博、鳥取大学工学部土木工学科（鳥取市湖山町南 4-101、TEL 0857-31-5283、FAX0857-28-7899)
つたもの ${ }^{6)}$ 、多様な主体が連携するための仕組みづくり を提案したもの ${ }^{7)}$ 等があるが、活動団体の活動実態や傾 向を考慮した研究は見当たらない。

このような背景から、本研究ではまず連携の主体であ る活動団体の活動内容を分析するとともに、活動団体を 類型化して活動の傾向を把握する。次に、その活動実態 と傾向をもとに、役割連携の観点から流域連携の連関構 造を明らかにする。そして、その連関構造から効果的な 役割連携の方途について幾つかの可能性と課題を指摘す ることで、流域連携の促進に有益な知見を示す。

\section{2. 活動団体の実態分析}

\section{（1）活動団体の集計方法}

活動団体の情報は「環境 NG0 総覧 平成 10 年度版」 ${ }^{8)}$ から得た。環境 $\mathrm{NG0}$ 総覧は全国の民間環境保全団体を対 象に、定期的に行われるアンケートによる実態調査の結 果である。記載されている団体 4, 227 団体から、川づく り、水循環の回復、生態系保全、水辺景観の保全等、川 や水に関連した活動を行っている活動団体をリストアッ プし、表ー1の項目について集計した。リストアップさ れた団体は計 1,800 団体で全体の約 4 割強に相当し、水 環境への関心の高さと多様な取り組みが伺えた。

\section{表- 1 活動団体情報の集計項目}

(1)名称、(2)所在地、(3)設立年、(4)広報（E-mail、ホームページ、会 報の有無)、(5)組織（スタッフ数、個人会員数、団体会員数、総収 入、総支出)、(6団体目的、(7)活動分野、8活動地域、(9)活動テー マ、(10活動内容 <大分類·中分類·小分類 (具体活動) $>$

\section{（2）全般的な傾向}

活動団体の全般的な傾向として、首都圏のように人口 が多く水環境に関する問題が多いと考えられる地域ほど 団体数が多い（図ー1）。ただし、大阪府は人口に比して 団体数が少なく、東京都は多い傾向がある。

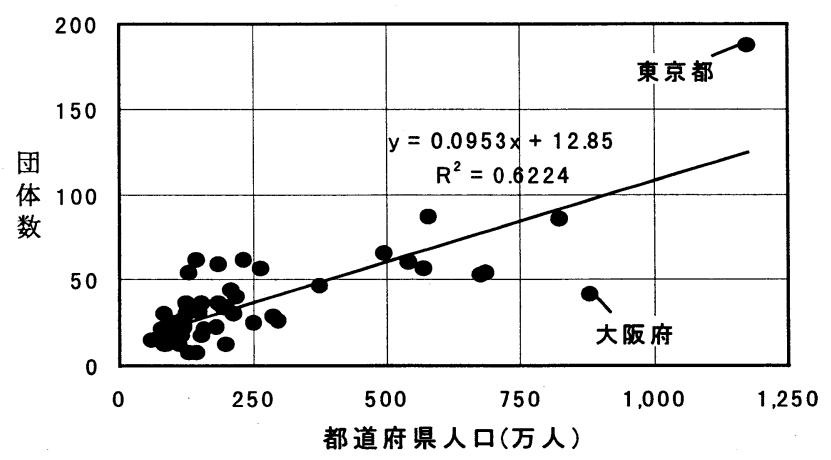

図- 1 都道府県人口と活動団体数の関係 


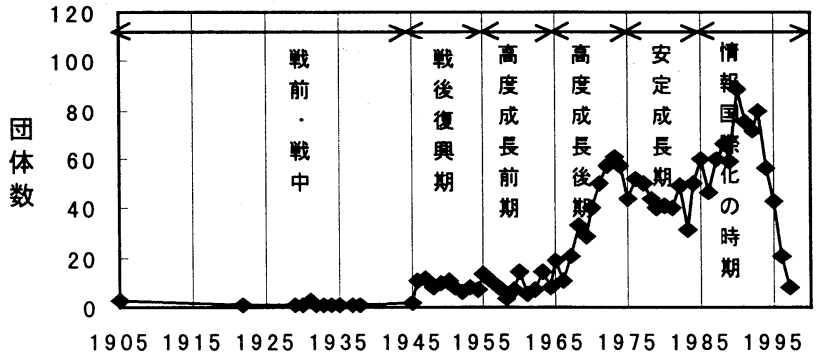

設立年

図ー2 活動団体の設立数の推移

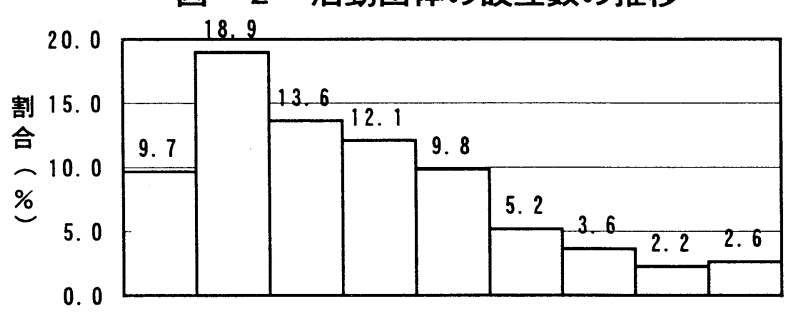

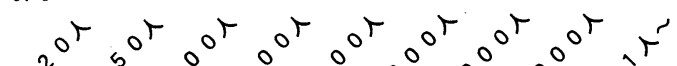

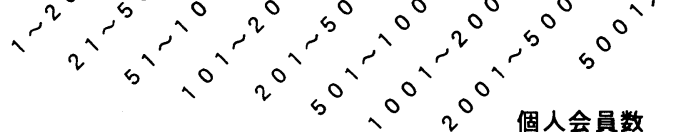

図-3 個人会員数の規模の分布

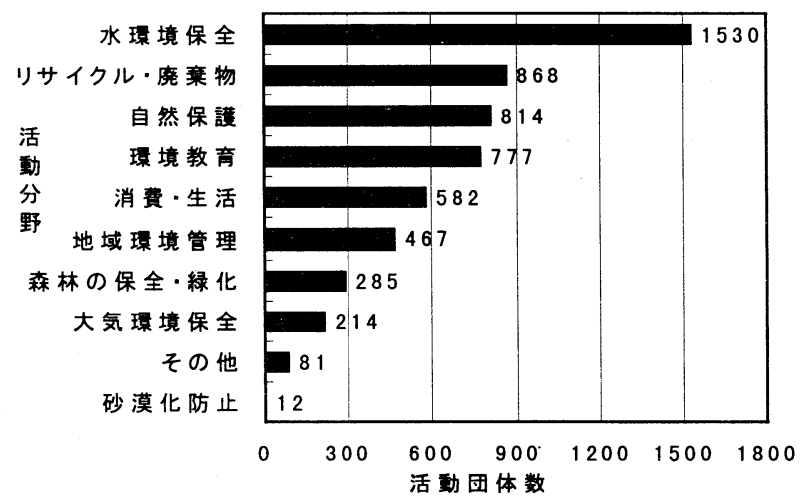

図-4 活動分野別団体数（複数回答）

団体の設立時期は、公害問題が深刻となり水質污濁 が進行した 1970 年代前半を第 1 のピークとし、その後 行政機関の水質保全対策が進展すると少なくなる (図 -2)。また地球規模の環境問題が注目され、地域レべ ルでも身近な自然環境の保全が強く意識されるようにな った 1990 年前後を第 2 のピークとし、その後少なくなる。 これは 1994 年から始まった多自然型川づくり等、行政機 関の取組みと関係があると考えられる。つまり活動団体 は、水環境問題に敏感に反応して設立され、行政機関の 対策が進展すると設立数が減少する傾向が読み取れる。 このような傾向は文献 3 ) でも確認されており、流域内で 新たな住民活動を活性化する際に考慮すべき点である。 また、最近の激減傾向は留意すべき現象と考えられる。

\section{（3）規模}

活動団体の大半は 500 人以下の個人会員を有し（図一 3 )、20人以下のスタッフで年間 100 万円以下の予算で運 営されている。団体の平均像 (中央値) は個人会員数 90 人 程度、10 名程度のスタッフ、年間予算 40 万円程度の比較 的規模の小さい団体であった。

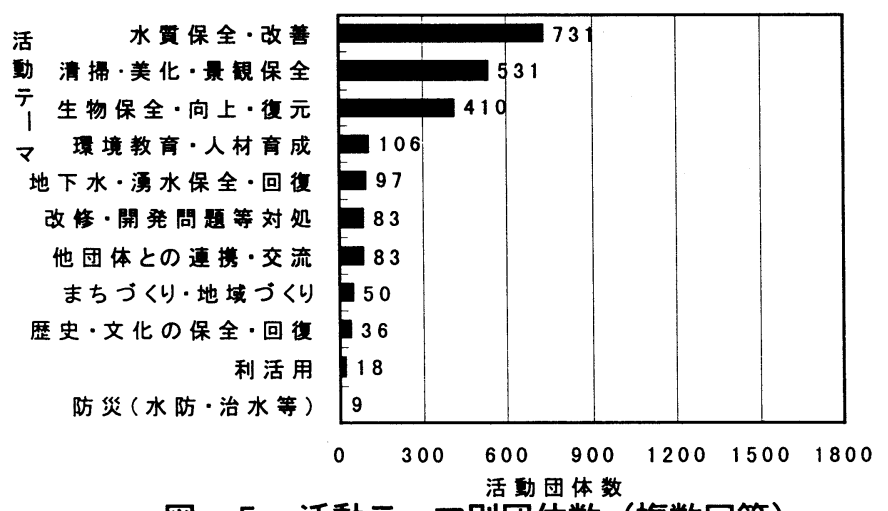

図-5 活動テーマ別団体数（複数回答）

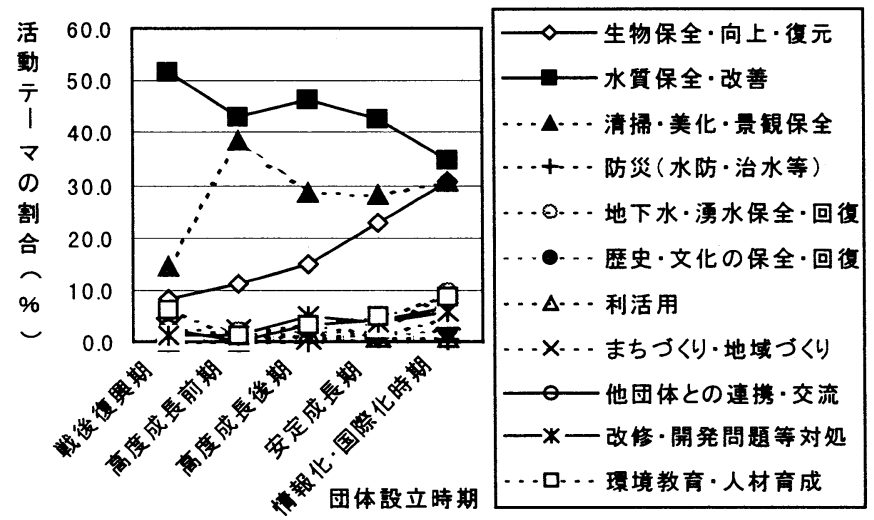

図ー6 設立時期と活動テーマ

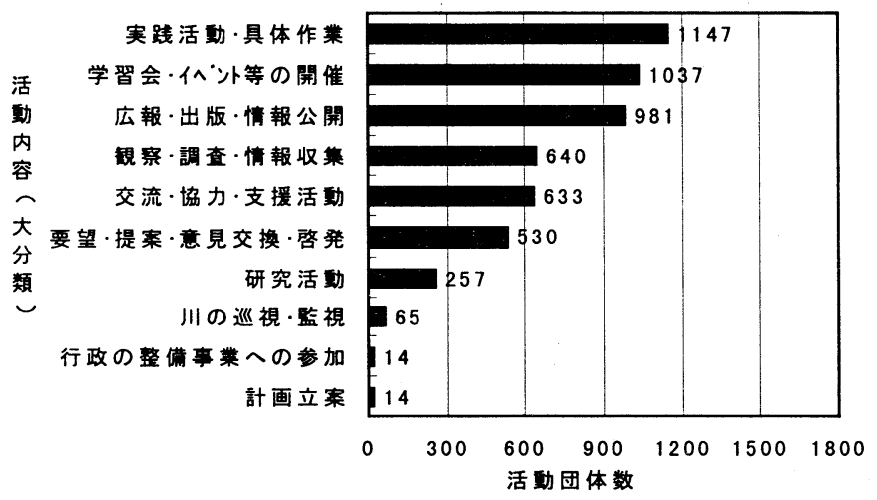

図-7 活動内容（大分類）別団体数（複数回答） （4）活動状況

a ）活動分野

活動分野では、「水環境保全」以外に「リサイクル・廃棄 物」、「自然保護」、「環境教育」等の分野で活動している団 体が多い(図一4)。また、多くの団体はそれらの活動分 野を 2〜4つ重複して多様な活動をしていた。なお、ここ で「水環境保全」と回答する団体数とリストアップ団体数 が一致しないのは、当該分野に「水環境保全」と記載され ていない場合でもその活動内容から水環境に関連する活 動を行っていると判断した団体があるためである。

b）活動テーマ

水環境に関連する活動を 11 テーマに分類した。その中 では水質保全·改善、清掃·美化·景観保全、生物環境の保 全·向上·復元の 3 つに多くが集中する(図－5)。水質保 全·改善は最も多いが、設立年が新しい団体ほど微減傾向 にある一方、生物環境の保全·向上·復元、環境教育·人材 育成、他団体との連携·交流等は新しい団体ほど多くなる。 清掃・美化·景観保全は横這いである(図一6)。 


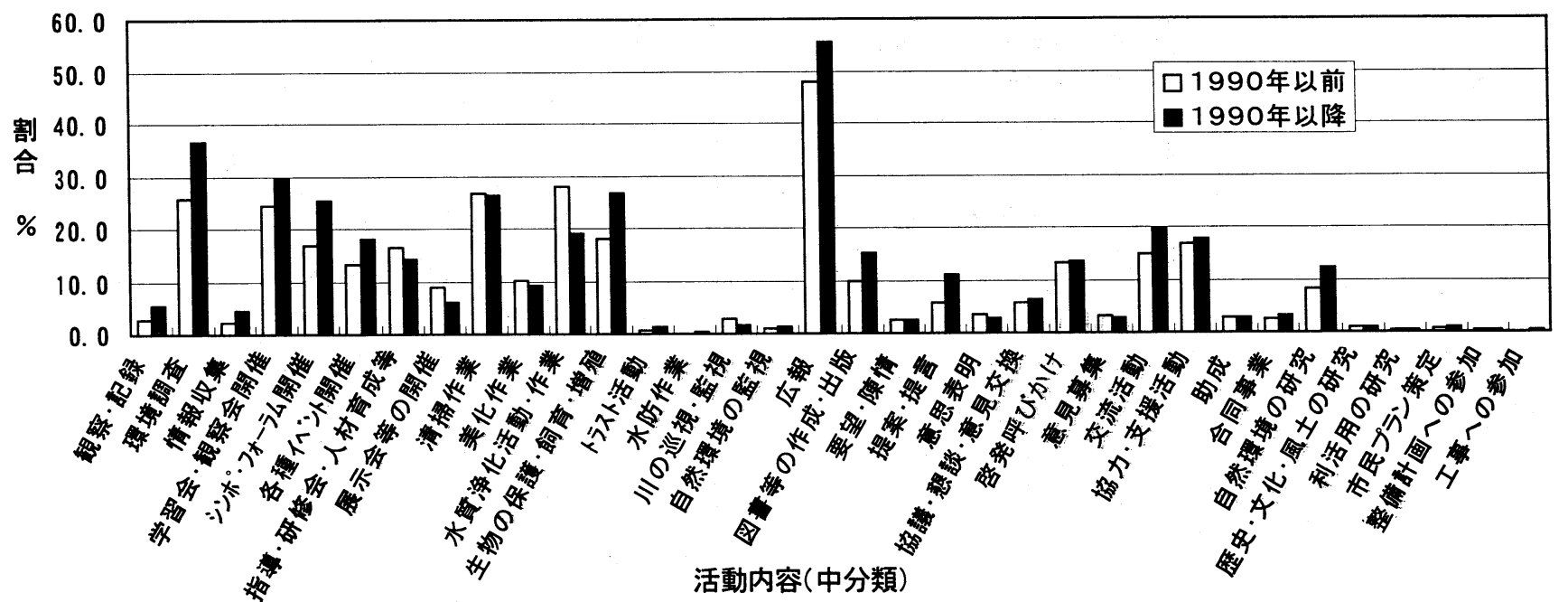

図－81990 年以降と以前に設立された団体の活動内容（中分類）の比較（複数回答）

表一2 活動団体の活動内容の分類

\begin{tabular}{|c|c|c|}
\hline 大分類 & 中分類 & 小分類（具体活動） \\
\hline \multirow{3}{*}{$\begin{array}{l}\text { 筧察·調査· } \\
\text { 情報収集 }\end{array}$} & 毁察·記録 & 生物䂓察、生物種の記録 \\
\hline & 環境調查 & 水質調查、生物調查、利用調查 \\
\hline & 情報収集 & 諸資料の収集、聞き取り \\
\hline \multirow{5}{*}{$\begin{array}{l}\text { 学習会・住 } \\
\dot{⿰} 卜 \text { 等の開 } \\
\text { 催 }\end{array}$} & 学習会·锤察会開催 & 室内学習会、野外臨察会、見学会、ビデオ鑑賞 \\
\hline & 汸ポ・フォーラム開倠 & 講演会、シンポジウム、討論会、フォーラム \\
\hline & 各理イベント開催 & $\begin{array}{l}\text { 川下り、川遊ひ、魚釣り、まつり、ハイキング・キ } \\
\text { ヤンプ、植樹際、コンサート、ライブ等 }\end{array}$ \\
\hline & 指導·研修会·人材育成等 & $\begin{array}{l}\text { 仗神ラクターの養成、スタッフの育成、セミナー、 } \\
\text { 野外研修会 }\end{array}$ \\
\hline & 展示会等の開催 & 写真展の開催、パネル展示 \\
\hline \multirow{6}{*}{$\begin{array}{l}\text { 実践活動·· } \\
\text { 具体作菜 }\end{array}$} & 清㨧作業 & 川そうじ \\
\hline & 美化作業 & 草刈り、花木の植裁、花壇の整備 \\
\hline & 水筫浄化活動·作業 & 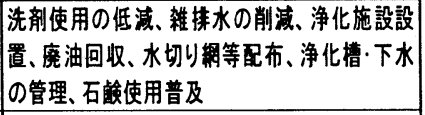 \\
\hline & 生物の保護·飼育·増真 & $\begin{array}{l}\text { 生物の保護飼育、生物の増殖、生物の移植·故 } \\
\text { 流等、植林·植裁、森林の手入れ }\end{array}$ \\
\hline & トラスト活動 & 用地の取得、立ち木トラスト \\
\hline & 水防作業 & 水防作業、水防訓練 \\
\hline \multirow[t]{2}{*}{$\prod_{\text {監視 }}$ 巡視· } & 川の巡視·パトロール & $\begin{array}{l}\text { 川の噮境パトロール、利用状況の巡視、川への } \\
\text { 不法投菓の監視 }\end{array}$ \\
\hline & 自然噮境の監視 & 水贒監視、生物種の監視、工事影䈉の監視 \\
\hline \multirow[b]{2}{*}{$\begin{array}{l}\text { 広報·出版· } \\
\text { 情報公開 }\end{array}$} & 広報 & 会報の発行、ホームページ \\
\hline & 图書等の作成·出版 & $\begin{array}{l}\text { 調㚗報告書等の作成、川の紹介書等の作成、 } \\
\text { パンフレッ、マップ、ビデオ作成、チラシ、ポスタ } \\
\text { 一、活動記録誌作成 }\end{array}$ \\
\hline \multirow{6}{*}{$\begin{array}{l}\text { 要望·提案· } \\
\text { 意見交換· } \\
\text { 管器 }\end{array}$} & 要望·陳情 & 要望·陳情書の提出 \\
\hline & 提案·提言 & 提案·提言書の提出 \\
\hline & 意志表明 & 反対アピール \\
\hline & 協倳·㺺談·意見交换会 & $\begin{array}{l}\text { 行政との協議·愳談·意見交換、他団体との基 } \\
\text { 談·意見交換 }\end{array}$ \\
\hline & 啓発呼びかけ & $\begin{array}{l}\text { 啓発アピール、看板等の設置、チラシ等の目 } \\
\text { 布、意見広告、広報誌に意見掲載 }\end{array}$ \\
\hline & 意見募集 & \begin{tabular}{|l} 
橒語·作品の募集、アンケートの実施、名川、名 \\
勝等の募集
\end{tabular} \\
\hline \multirow{4}{*}{$\begin{array}{l}\text { 交流·協力· } \\
\text { 支援活動 }\end{array}$} & 交流活動 & 他団体との交流、行政との交流 \\
\hline & 協力·支援活動 & $\begin{array}{l}\text { 他団体への協力·支援、行政への協力、講師の } \\
\text { 派遣、講演会等への参加 }\end{array}$ \\
\hline & 助成 & 活動への資金提供、一般住民への補助 \\
\hline & 合同事業 & イベントの共催、学習会·研修会の共倠 \\
\hline \multirow{3}{*}{ 研究活動 } & 自然環境の研究 & 生物の研究、地形·地質の研究 \\
\hline & 歴史·文化·国土の研究 & 川との関わり研究、川の民話研究、土木史研究 \\
\hline & 利活用の研究 & ワイズュースの検討、水面利用の検討 \\
\hline 計画立案 & 市民プラン策定 & 市民プラン策定 \\
\hline \multirow{2}{*}{$\begin{array}{l}\text { 行 政事 業 } \\
\text { ヘの参加 }\end{array}$} & 整備計画への参加 & 整備計画策定への参加 \\
\hline & 工事への参加 & 工事への協力 \\
\hline その他 & その他 & 子の他 \\
\hline
\end{tabular}

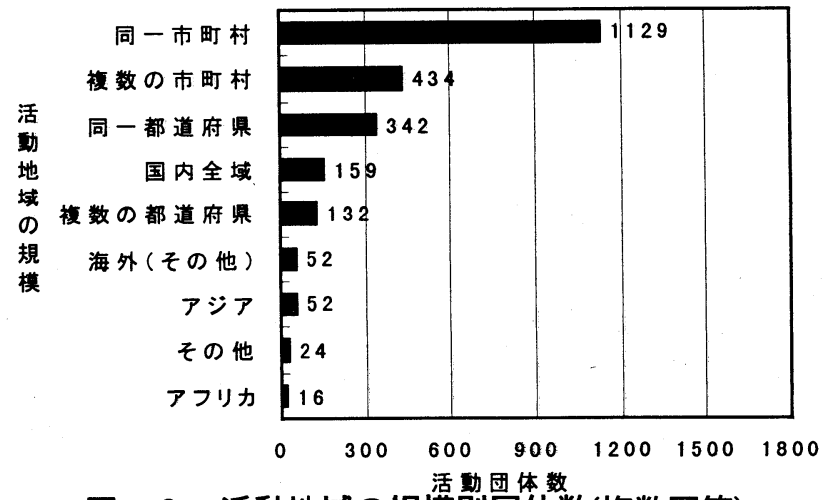

図-9 活動地域の規模別団体数(複数回答)

c ）活動内容

水環境に関する具体的な活動内容について、類似の活動 をまとめ、統合することで、11 の大分類、35 の中分類、 100 の小分類(具体活動)に分類した (表-2)。この中では、 河川清掃や水質净化の活動に代表される実践活動·具体 作業と学習会·イベント等の開催、広報·出版・情報公開は 大半の団体が行っている(図-7)。

また中分類でみると、最近設立された団体では、環境 調査や学習会·観察会、シンポジウム・フォーラムの開催 や、生物の保護·飼育・増殖、自然環境の研究等を行う傾 向が強くなっている一方、水質净化活動·作業はやや少な くなっている(図一8)。

d）活動地域の規模

活動地域は同一市町村の範囲が大半で、活動は比較的 小さい範囲にとどまっている(図ー9)。これは、活動対 象としている河川・水辺の規模や、活動の基盤となるコミ ユニティと関連があると考えられる。一方、複数の市町 村や都道府県にわたって活動する団体も少なくはない。

活動地域の規模と活動テーマの関連をみると(図-10)、 活動地域の規模が小さい団体ほど清掃・美化・景観保全が 多くなり、水質保全·改善は同一市町村〜同一都道府県の 規模の団体が、ほぼ同程度行っている傾向がある。一方、 生物環境保全·向上·復元というテーマは、様々な地域規 模で取り組まれている。また総収入規模や個人会員数は、 活動地域規模が小さくなるほど減少する傾向があった。 


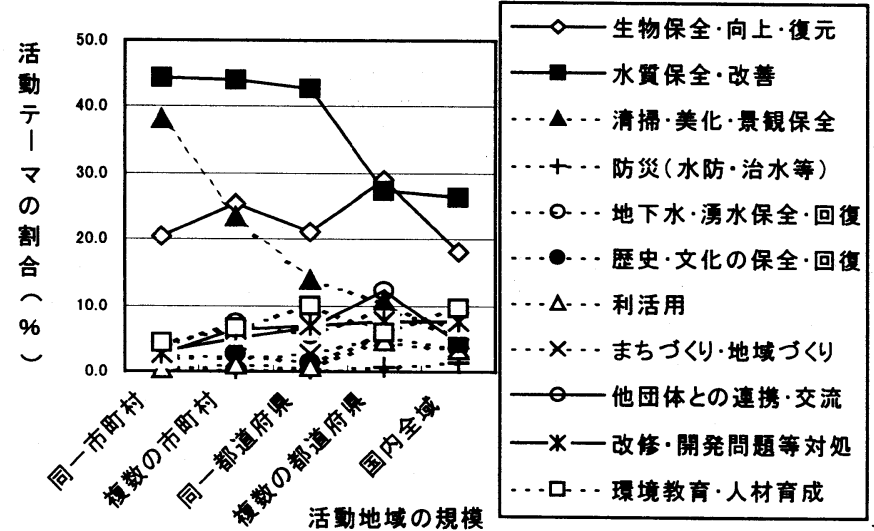

図-10 活動地域規模と活動テーマ

\section{3. 活動内容の傾向分析}

\section{（1）活動分野と活動内容のコレスポンデンス分析}

活動分野と活動内容（中分類）の関連性をみるため、 コレスポンデンス分析を行った（図ー11）。コレスポンデ ンス分析は 2 つ項目間のクロス集計をもとに、項目要 素の関連性を分析する手法である。その結果から、活動 団体の活動傾向に着目すると以下が指摘できる。

(1)生物の環境保全に関わる団体、水質净化に関わる団体、 清掃·美化を行う団体では、各々グラフ上の位置が離れ て分布している (図中の○で囲んだ部分)ことから、活 動の傾向が異なる。

（2「消費·生活分野」及び「リサイクル・廃棄物分野」の団体 は水質浄化の具体作業を行い、啓発呼びかけや協議·懇

談·意見交換を行う傾向も強い。

(3)「自然保護分野」や「森林の保全·緑化分野」の団体は生 物保全に関わる活動が多く、提案·提言、要望·陳情等 の能動的な働きかけを行う傾向が強い。

(4)「地域環境管理分野」の団体は清掃作業と美化作業だけ を行う傾向がある。

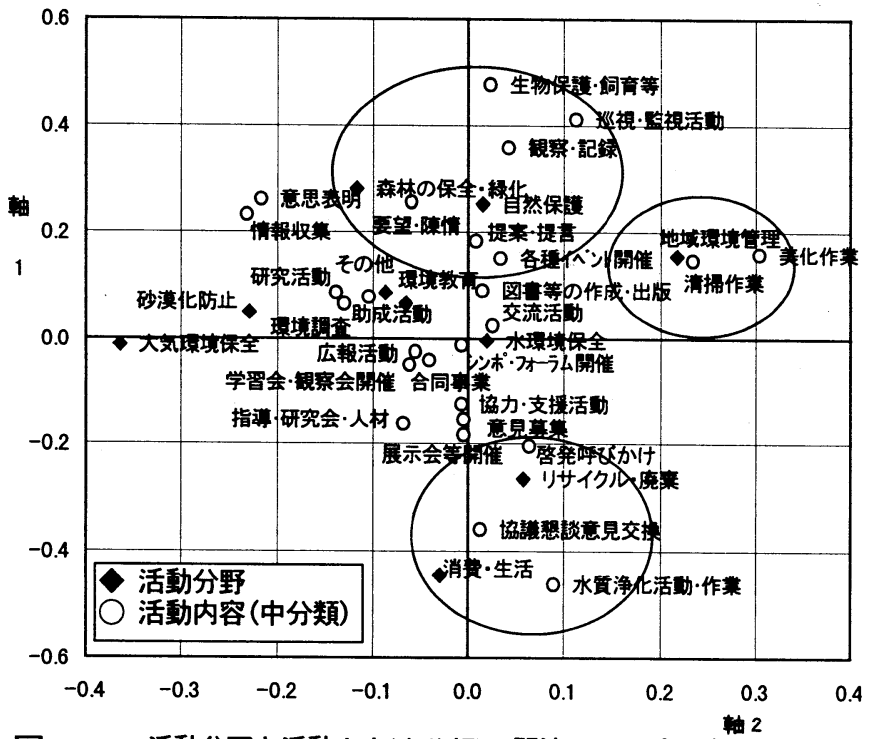

図ー11 活動分野と活動内容(中分類)の関連(コレスポンデンス分析)

\section{（2）数量化理論 3 類による活動内容の傾向分析}

以上の検討から、活動団体は活動内容による類型が可 能と推察されるため、活動内容（中分類）を用い数量化 理論 3 類による分析を行った。分析では軸解釈を容易に するため、該当団体数が 100 団体 (約 5.6\%) 以上のカテゴ リーを用いた。その結果、相関係数が 0.5 以上の軸とし て計 5 軸が評価でき、活動の多彩性が示唆された（図一 12)。軸の解釈は以下の通りである。

\1軸：美化作業、清掃作業の野外実践的な作業が正側に、負 側に協議·琶談·意見交換等の室内作業が位置し「野外実践一室 内活動〉軸之解釈される。（ $\mathrm{R}=0.67 ）$

- 2 軸: 水質浄化活動·作業や啓発呼びかけの水質浄化の関連活 動が正側に、負側に生物保護·飼育·增殖や提案·提言等の生物保 全の関連活動が位置し「水質浄化一生物保全活動]軸と解釈され る。 $(\mathrm{R}=0.59)$

- 3 軸 : 協議·懇談·意見交換や提案·提言の外交·対話的活動が 正側に、負側にイベント開催や生物保護等の自主企画的な活動 が位置し「外交一自主活動 軸と解积される。（ $R=0.54 ）$

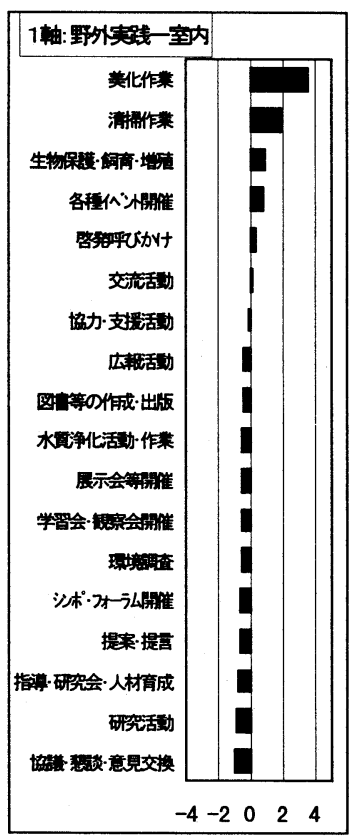
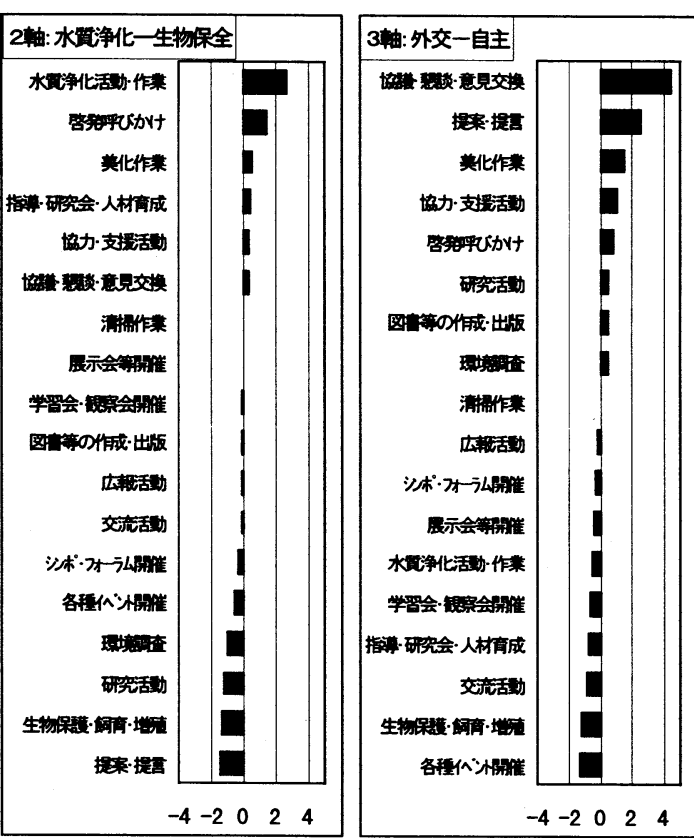

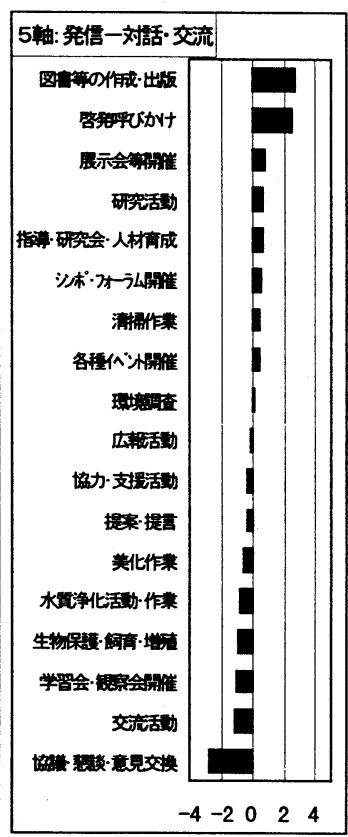

図-12 活動内容 (中分類: 統合)の饬コ尚-不了（数量化理論 3 類による分析結果) 

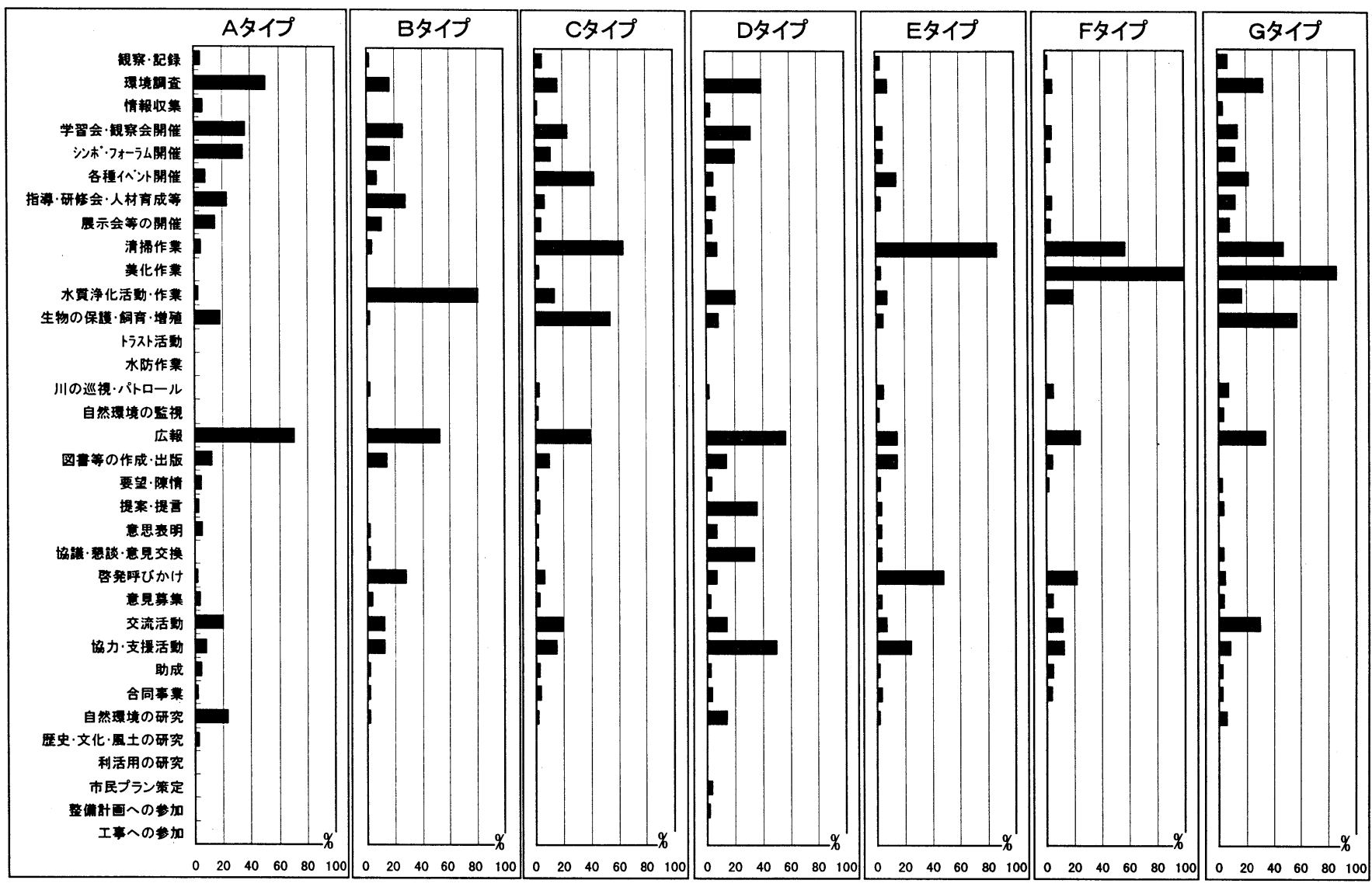

図一13 タイプ別にみた活動内容(中分類)の割合

4 軸 : 各種イベント開催や協力·支援活動、提案·提言等の他 主体へ動的に働きかける活動が正側に、負側に美化作業や展示 会開催等の静的に働きかける活動が位置し「動的一静的活動」軸 と解釈される。（ $\mathrm{R}=0.53 ）$

○軸: 図書等の作成·出版や啓発呼びかけ等の発信型の活動が 正側に、負側に協議·懇談·意見交換や交流活動等の対話·交流的 な活動が位置し「発信一対話·交流活動」軸と解釈される。（R= 0. 52)

\section{（3）活動団体の類型化}

数量化理論 3 類から得られた 5 つの軸によるサンプル スコアを用いて活動団体のクラスター分析を行った（原 データの距離計算はユークリッド距離、合併後の距離計 算はウォード法)。その結果、活動団体の活動夕イプは計 7 つの類型に分類された。各類型の特徵を把握するため、 活動規模や分野、テーマ、活動内容等の項目とクロス集 計を行った結果、各類型は表ー 3 に示すタイプであると 判断された。また、各タイプと活動内容（中分類）の関 係を図一 13 に示す。

これら類型化された 7 タイプについて、年代別にその 設立割合をみると、B タイプは近年大きく割合が減少傾向 にある一方、A、Cタイプは増加傾向にある（図一-14）。ま た E、Fタイプは微減傾向で、Dタイプは微増傾向にある。 すなわち、水質净化単独、清掃·美化単独の団体の設立が 少なくなり、生物保全に取り組み、環境調査や学習的な 活動、イベント、対話等多様な活動を展開する団体の設 立割合が近年多くなっていると言える。
表一 3 活動団体のタイプ類型

\begin{tabular}{|c|c|c|}
\hline 夕1170 & 割合 & 活動の傾向 \\
\hline $\begin{array}{l}\text { A 調べ学ぶ } \\
\text { 自主学中 } \\
\text { 心型 }\end{array}$ & $\begin{array}{c}n= \\
473 \\
26.7 \%\end{array}$ & $\begin{array}{l}\text { 生物保全系と水質浄化系が同程度存在するが、 } \\
\text { 実践活動や対外的な活動よりも調査·研究活動 } \\
\text { や钼察·学習会、シンボジウム開催、広報等の自 } \\
\text { 主的で学習的な活動が中心である。規模として } \\
\text { は小〜大規模な団体まで様々。 }\end{array}$ \\
\hline $\begin{array}{l}\text { B 生活から } \\
\text { 水䪹に配慮 } \\
\text { 型 }\end{array}$ & $\begin{array}{c}n= \\
389 \\
22.0 \%\end{array}$ & 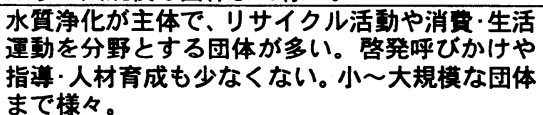 \\
\hline $\begin{array}{l}\text { C実践する } \\
\text { 行動的な生 } \\
\text { 物保讙型 }\end{array}$ & $\begin{array}{c}n= \\
348 \\
19.7 \%\end{array}$ & 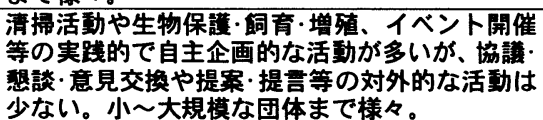 \\
\hline $\begin{array}{l}\text { D考え対話 } \\
\text { する環境保 } \\
\text { 全型 }\end{array}$ & $\begin{array}{l}n= \\
250 \\
14.1 \%\end{array}$ & 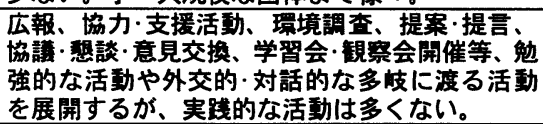 \\
\hline $\begin{array}{l}\text { E 川そうじ } \\
\text { 主体型 }\end{array}$ & $\begin{array}{l}n= \\
125 \\
7.1 \%\end{array}$ & $\begin{array}{l}\text { 清掃作業が主体で、啓発呼ひかけや強力·支援活 } \\
\text { 動も少なくない。規模としては地域密盖の小規 } \\
\text { 模な団体が多い。 }\end{array}$ \\
\hline $\begin{array}{l}\text { F 川を美化 } \\
\text { する実践型 }\end{array}$ & $\begin{array}{l}n= \\
96 \\
5.4 \%\end{array}$ & $\begin{array}{l}\text { 草刈りや、花の植栽等の美化活動が主体であり、 } \\
\text { 清掃作業も多い。地域密着の小規模な団体多い } \\
\text { 一方、大規模な団体も存在する。 }\end{array}$ \\
\hline $\begin{array}{l}G \text { 実践·交 } \\
\text { 流する地域 } \\
\text { 環境保全型 }\end{array}$ & $\begin{array}{l}n= \\
90 \\
5.1 \%\end{array}$ & $\begin{array}{l}\text { 美化や清㛿作業、生物保護·咱育·増殖等の多忮 } \\
\text { に渡る実践活動を行っている。また広報や環境 } \\
\text { 調查、交流活動も少なくない。地域密著の小規 } \\
\text { 模な団体が多い。 }\end{array}$ \\
\hline
\end{tabular}

\section{4. 流域連携の連関構造分析と考察}

\section{（1）分析の目的と方法}

以上から活動団体は概して小規模で地域に密着した活 動を行い、7タイプの活動傾向があることが分かった。 つまり、地域地域で様々な活動が行われている訳である が、これらが互いに連携し流域規模の取組みができれば 水環境保全活動に新たな展開が開けると考えられる。こ こでは、これらの活動団体の諸活動は流域を単位とした 


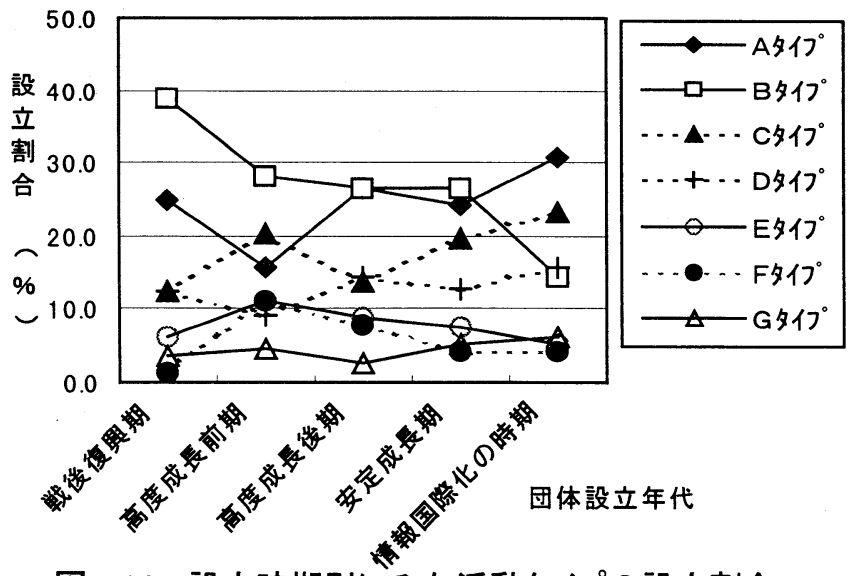

図ー14 設立時期別にみた活動タイプの設立割合

取組みの部分的な「役割」を担いうるという仮定のもと、 7 タイプの活動団体や河川管理者、地方自治体、専門家、 企業、一般住民等の連携のあり方を探るため、役割連携 の観点からその連関構造を ISM 法 ${ }^{9)}$ によって分析する。

流域連携のテーマには、川づくりや水環境保全、管理、 環境教育、地域活性化、福祉等様々あり、各地で多様な 取組みがみられる ${ }^{10}$ 。ここでは流域連携のテーマに、「川 づくり」と「水環境管理」の 2 つを設定する。「川づくり」や 「水環境管理」とは本来広範な意味を含むが、ここでは「川 づくり」は流域で展開される多自然型川づくり等の河川 改修工事として捉え、「水環境管理」は水辺の景観、水質、 水量、生態系を望ましいように維持·管理及び改善する行 為として限定的に捉える。(「川づくり」を選んだのは、河 川法の改正を受け全国で河川整備計画が住民参加で策定 されようとしているためでもある。）

分析にあたり、まず上記 2 テーマに関連する各主体の の活動内容をリストアップした。活動団体については表 -2 の活動内容(中分類)を採用した。但し、「川づくり」 では清掃や浄化活動等の維持管理に関る実践活動·具体 作業は使用しなかった。また、「水環境管理」では水防活 動を主な関連がないと考え使用しなかった他、研究活動 は「自然環境等の研究」として一括した。次に河川管理者、 地方自治体、専門家、企業、一般住民が 2 テーマに関し 担うべき活動(または役割)を文献 11)、12）等を参考にリ ストアップし加えた(図-15、16 の左の表)。この他、「水 環境管理」は「生態系保全」、「水辺景観の維持·管理」、「水 質の保全」、水量の保全」に分類できるため、構造グラフ を見やすくするため便宜上これらの項目を加えた。

ISM 法の関係ステートメントRは、「活動 $\mathrm{i}$ は活動 $\mathrm{j}$ に 著しく貢献するか」とし、この関係が成立する場合に「i $\rightarrow \mathrm{j} 」$ とて隣接行列を作成し演算を行った。しかし、 実際には $\alpha$ という活動が $\beta$ という活動に貢献し、その $\beta$ の活動がまた $\alpha$ の活動に貢献する循環構造もありうるが、 構造の単純化のためここでは省略する。なお、関連性の 判断は第一著者が実際に活動団体の活動に参加した経験 や、諸事例の実態観察に基づくことを断っておく。

ISM 法による「川づくり」と「水環境管理」の構造グラフ を図ー15、16 に示す。図中の左の表は、各主体の諸活動(役
割)の関連性を階層順に整理したものである。またここで 活動団体の各タイプについては、図-13 から各々 2 割以 上が行っている活動を関連ありとして「」を付している。 この図は、いわゆる「川づくり」と「水環境管理」に向け た役割連携の可能性を構造化したものであり、テーマの 対処に図中の各活動が全て必要という意味ではない。例 えば、ある活動 $\gamma$ をさなくとも、図中の矢印がその活 動 $\gamma を$ 越えて上方につながっていけば、「川づくり」や「水 環境管理」の 2 テーマは実行できる。但し、そこに至るプ ロセスの中でその $\gamma$ の活動が役立つという意味である。 このため、この図は各流域における役割連携の点検や問 題点発見、戦略立案等に活用することが有効である。

しかしここでは、図の連関構造の中身を考察すること で、役割連携の可能性と課題を例示的に指摘し、手探り 状態にある各地の流域連携の取組みに参考情報を示すこ とを試みる。

\section{（2）「川づくり」に関する連携について}

a) 連関構造の特徵と関連する団体の活動分布

図ー15 に示すように、「川づくり」に関連する各主体の 諸活動は、幾層もの階層構造 (計 13 層)に区分される。つ まり、可能性としてこれらが「川づくり」に向けて段階的 に役割連携されれば、諸活動が有機的に機能する。しか し、水環境に関わる活動団体は、先にも示した通り活動 地域の範囲が狭く、複数の活動団体が同様の地域に重複 して存在しているとは必ずしも限らない。 活動団体の諸活動は、概ね以下の 4 段階に分布する。

(1) Dタイプが行う「6 協議·郎談·意見交換」や「9 提案·提言」等の 提案·対話型活動や B、E、Fタイプの「12 啓発呼びかけ」の 活動

(2) A、B、C、D、Gタイプ等が行う「16 学習会·観察会開催」 や「17 各種野外イベント開催」「19 シンポ・フォーラム開催」 「22 広報」、「23 他団体との交流活動」等の学習·交流行事的な 活動

(3) A、D、Gタイプが行う「26 環境調査」や「24 自然環境の研究」 等の調査·研究的な活動

(4) A、Bタイプが行う「27指導·研修会・人材育成等」の活動やD 、 Eタイプが行う「31 協力・支援」等の活動支援的な活動

b）調査·研究的な活動との連携と広域化

A、D、Gタイプが行う「26 環境調査」やAタイプの「24 自然環境の研究」は、「川づくり」の基礎情報を収集する役 割を果たしうる。このため、このような活動を流域の広 範囲で展開することが「川づくり」に有益である。A、D、 Gタイプの活動範囲を拡大する、もしくは、地域地域で このようなタイプを新たに育成することが重要である。

実際にこのような活動は各地で盛んになっている。例 えば環境調査では、近年簡易な水質調査の器具が開発さ れたことから、身近な川の主な水質調查は専門家だけで はなく一般住民でも可能となり、全国各地で住民参加に よる流域規模の水質調査が盛んに行われるようになった 13)。そこでは、様々な活動団体、一般住民、学校等が参 加し、流域の水質の経年データが蓄積されるとともに、 


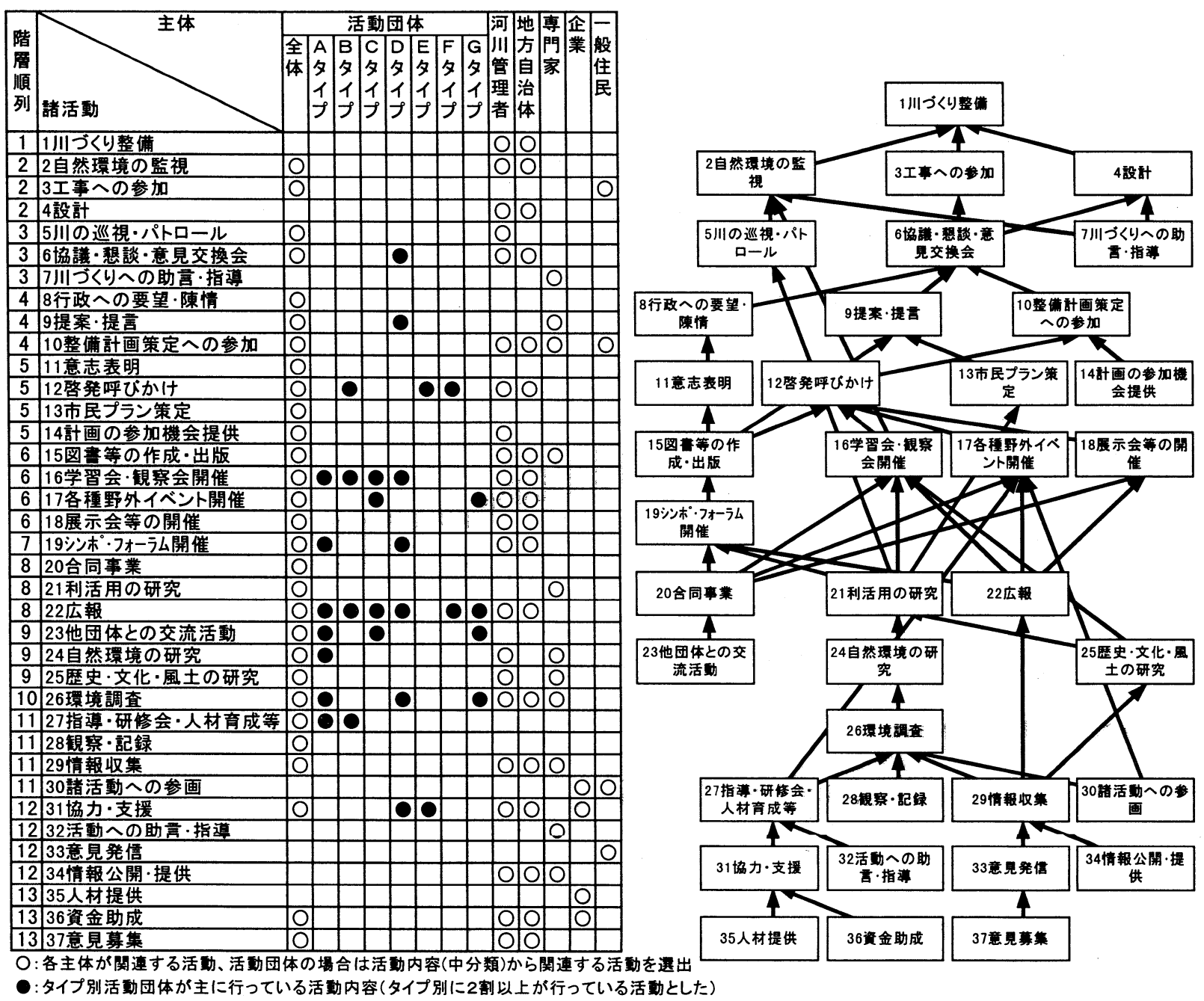

図ー15「川づくり」における諸活動の連関構造（ISM 構造グラフ）

地域の専門家の参加で研究的な活動への展開が模索され ている ${ }^{14)}$ 。生物調查についても、専門家の協力を得なが

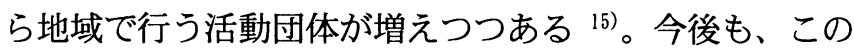
ような取組みを支援する簡易な調査手法の開発や、河川 管理者や地方自治体、企業等の活動支援、人材育成、地 域の専門家や研究者の参画等が必要である。また、様々 な団体、学校、一般住民等へ、身近な川の環境調査や研 究を普及させていく必要がある。

Aタイプの研究的な活動としては「24 自然環境の研究」 が多いが、その他に「21 利活用の研究」や「25 歴史·文化· 風土の研究」がリンクできれば、より「川づくり」に有益な 情報を提供しうる。ただし、このような研究を行う活動 団体は少なく、地域の専門家、河川管理者、地方自治体 が研究を行っていることが多い。このような分野の専門 家の参画や、行政の情報提供等が必要である。

c）提案·対話的な活動との連携と広域化

$\mathrm{D}$ タイプの $「 9$ 提案·提言」や「6 協議·懇談·意見交換」等 の提案·対話型の活動は、自ら行う「 26 環境調査」の他、日 常的な体験や意識が基礎情報となっていると考えられる が、これにさらにAタイプ等の調査・研究的な活動がリン クされれば、地域の環境情報が提案・対話に活かされる。 そして、「川づくり」の整備計画策定にAタイプ等の有す る環境情報や研究成果等を反映しうる。このため、A夕
イプはDタイプの提案・対話型の活動を行う能力を、D夕 イプはAタイプの研究能力をそれぞれ会得するよう支援 することが考えられる。そのためには、専門家の助言·指 導や、両者の構成員の人材交流等が考えられる。

また、Dタイプの活動範囲を広域化することができれ ば、地域に散在する諸情報や研究成果を収集し、「川づく り」について提案·対話する活動が活発化する。昨今、各 地で流域連携を促すセンター的組織の設立が提案されて いる7)が、「川づくり」に向けた連携には、その組織がD タイプのような役割を担うことが重要と言える。そこで は、様々な情報や研究成果を提案・対話に反映するための 専門的な知識を有し、対話や交渉力を備えるコーディネ 一ターを育成すること ${ }^{16)}$ が肝要である。実際に、流域連 携を促す団体がこのような役割を担うことで、「川づく り」に活動団体の諸活動が活かされた事例もあり ${ }^{17) 、 こ の ~}$ 指摘の有効性が確認できる。

AタイプとDタイプの活動の結節点は、「19 シンポ・フ オーラム開催」や「15 図書等の作成·出版」である他に、「13 市民プラン策定」を行うことである。このことは害際に、 住民の活動を通して得られた諸情報が、地域の専門家の 活動参加によって川づくりの市民プラン策定に反映され た事例があることからもその有効性が確認できる ${ }^{15)}$ 。し かしながら、このような「13 市民プラン策定」が行える活 
動団体は少ない。このため、活動団体に対して計画策定 能力を高めるための人材育成の支援や、地域の専門家の 参加と助言·指導の機会を活発化することが肝要である。

Aタイプ等の調査・研究活動を、河川管理者が行う「川 づくり」の整備計画に直接反映することも考えられる。し かし、同じ流域にDタイプのような団体が存在する場合 には、Dタイプの意見や提案も入れて対話する必要があ る。そうでなければ、流域全体の合意形成になりえない。 このため、河川管理者は「14 計画の参加機会提供」によっ て、Dタイプ等、様々な活動団体に計画策定への参加を 促すことが必要である。また、そうすることで、住民活 動から得られる意見や情報を川づくりに反映することが できる。

\section{d）学習·交流行事的な活動との連携}

「16 学習会·観察会開催」や「19 シンポ・フォーラム開催」、 「22 広報」「23 他団体との交流活動」がA、C、D、G夕 イプにある程度重複する活動内容である。流域内におい て、学習会や観察会、シンポジウム、フォーラム等を多 様な活動団体の参加で開催することで、団体間の連携が 促されたり、あるタイプの活動が他方へ伝播する可能性 がある。実際に、このような機会が活動団体間のコミュ 二ケーション、情報交換の場となっていることは多い ${ }^{18)}$ 。 e ）他の主体の役割と連携

専門家や研究者の役割としては、自ら行う調査・研究 の他、「32 活動への助言·指導、「10 整備計画策定への参 加」、「7川づくりへの助言・指導 $」$ 等がある。活動団体の育

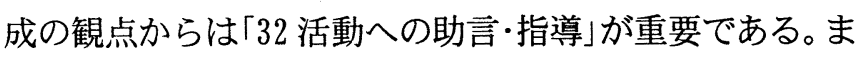
た今後は先にも示した通り、調査・研究活動や市民プラン 策定に対する助言·指導が望まれる。企業や河川管理者、 地方自治体等が行う「36 資金助成」や「 35 人材提供」等の支 援は、住民活動を底辺で支える役割を果たす。河川管理 者や地方自治体の「34 情報公開·提供」も活動を底辺付近 から支援する。一般住民の関わりとしては、活動団体に 対する「33 意見発信」や「30 諸活動への参画」と、河川管理 者が呼掛ける「10 整備計画策定への参加」「3 工事への参 加がある。

\section{（3）「水環境管理」における連携について}

a ）連関構造の特徵と関連する団体の活動分布

図ー16 から「水環境管理」には、7タイプ全ての活動団 体、河川管理者、地方自治体、及び専門家等の役割が密 接に関連しうることが分かる。また、諸活動は幾層もの 階層構造(計 15 層)から成立している（下層の連関構造は 先の「川づくり」と同様である)。これらのことから「水環 境管理」を実践するには、多くの主体の参画により段階的 に役割連携する必要があると言える。

活動団体の諸活動は、概ね以下の 5 段階に分布する。

(1) B、C、D、E、F、Gタイプが行う「4 生物の保護·飼育·増 殖」、「6 清掃作業」、「7 美化作業 (草刈り、植栽等) 」、「9 水 質浄化活動·作業」等の具体·実践的な活動
(2) Dタイプが行う「20協議·根談·意見交換」や「24 提案·提言」等 の提案·対話型の活動やB、E、Fタイプの「(ツ)啓発呼びか け」の活動

(3) A、B、C、D、Gタイプ等が行う「31 学習会·観察会開催」 や「34 シンポ・フォーラム開催」「「37 広報」、「38 他団体との 交流活動」等の学習·交流行事的な活動

(4) A、D、G夕イプが行う「39 環境調査」や「36 自然環境の研究」 等の調査·研究的な活動

(5) A、Bタイプが行う「40指導·研修会・人材育成等」の活動やD、 Eタイプが行う「 44 協力・支援」等の活動支援的な活動

b) 具体·実践的な活動の連携

上記(1)の具体·実践的な活動は、「水環境管理」に直接的 な効果があると言える。しかし、これらは多くの参加者 が必要な活動でもあり、このような活動を流域規模で連 携したり、活発化することが必要である。この具体·実践 的な活動は、その効果が目に見え、活動に楽しさが加味 できれば、多くの住民が参加しやすい活動である5)ため、 今後さらに参加拡大を促す工夫が必要である。実際に近 年、このような工夫により流域規模での河川清掃が盛ん になっている流域もある2)。

c）調査·研究的な活動との連携と広域化

A、D、Gタイプの行う調査・研究的な活動は、「川ブ くり」の連携と同様に、「水環境管理」に向けた地域情報を 収集する役割を果たしうる。このため、このような活動 を流域で広範囲に展開できれば有益な情報収集につなが る。すなわち、調査・研究的な活動を広域化したり、地域 地域で新たな団体を育成することが必要である。また、 従来は河川管理者や地方自治体が行ってきた調査・研究 的な活動を、活動団体が代替する可能性もありうる。

先にも示した通り、今後もこのような取組みを支援す る簡易な環境調査手法の開発や、河川管理者や地方自治 体、企業等の活動支援、人材育成、地域の専門家や研究 者の参画等が必要である。また、様々な活動団体、学校、 一般住民等へこれらを普及させていく必要がある。

d）提案·対話的な活動との連携と広域化

(1)と(2)の間には河川管理者や地方自治体の担う「10 環 境修復整備」や「11 下水·浄化事業」「「13 水資源の適正·有 効利用」、「16 水源、浸透域の保全·復元 等の公共事業と、 一般住民の「12 家庭での配慮」や「17 保全·管理作業への参 加」が介在する。この内公共事業に対しては、先の「川づ くり」と同様にDタイプの提案・対話型の活動やA、D、 G夕イプの調査・研究的な活動がリンクできるように支 援することが有益であると考えられる。そうすることで、 地域の環境情報や研究成果が公共事業に反映できる。そ のため、専門家の助言·指導や、活動団体構成員の人材交 流等が必要である。

また、Dタイプの活動範囲を広域化して、地域の環境 情報や研究成果を収集し、行政へ対話·提言したり、具体・ 実践的活動をコーディネートする役割を強化することも 有益である。やはり「水環境管理」でも、流域連携のセン ター的組織がD タイプのような役割を備えることが重要 である。そして、ある程度の専門的な知識を有し、対話 や交渉力を備えるコーディネーターを育成することが肝 


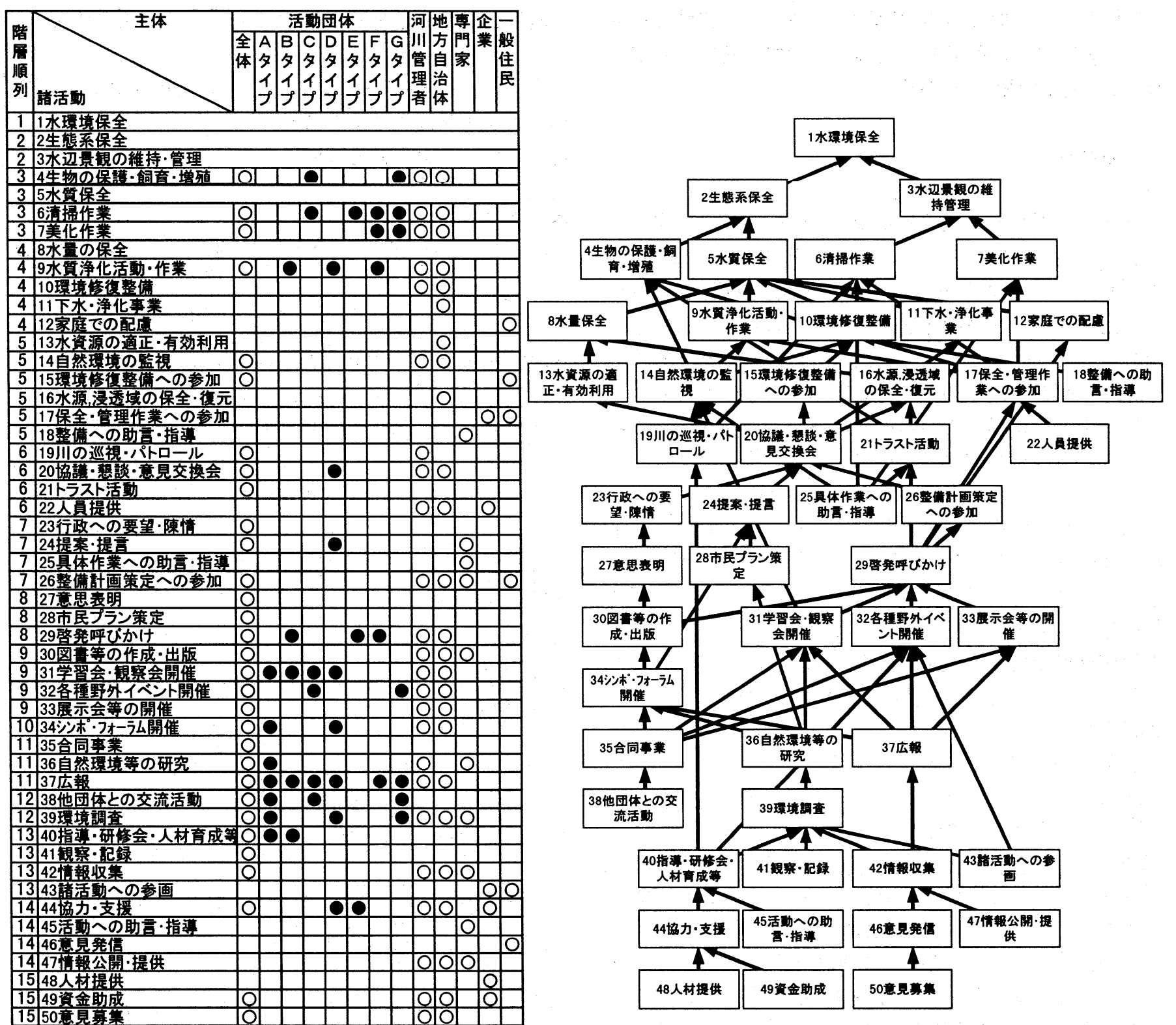

O:各主体が関連する活動、活動団体の場合は活動内容(中分類)から関連する活娌を選出

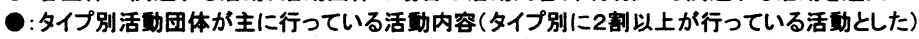

図ー16 「水環境管理」における諸活動の連関構造(ISM 構造グラフ)

要である。

e ）学習·交流行事的な活動との連携

A、D、Gタイプの調查・研究的な活動が、A、B、C、

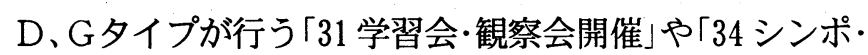
フォーラム開催」等の学習·交流行事的な活動を介して、

B、E、Fタイプの行う「29 啓発呼びかけ」にながれば、 一般住民の「17 保全·管理作業への参加や「12 家庭での配 慮」等の具体行動に、地域の環境情報が伝達されるととも に、活動参加が促されると考えられる。つまり、学習·交 流行事的な活動を流域規模で活発化すれば、一般住民の 地域に即した適切な行動が促される。

またそのような意味では、EやFタイプのように具体・ 実践活動だけを行う団体よりも、BやGタイプの学習·交 流行事的な活動を併せて行う方が望ましい形態と言える。 EやFタイプのような団体は、一般的に町内会や自治会 等の地域コミュニティが多いと考えられるが、そのよう な活動に地域の環境情報や助言を与える活動団体の存在
が必要である。このような連携の有効性は例えば、北海 道の茂漁川で地域コミュニティが行う河川愛護活動に対 し、専門的知識を有する NP0 が活動の助言を行うことで よりよい活動が模索されていることからも確認できる11)。 f ）他の主体の役割と連携

「水環境管理」については河川管理者の事業は限定的で、 地方自治体の担う「11 下水·净化事業」「13 水資源の適正· 有効利用」、「16 水源、浸透域の保全·復元」等が重要であ る。活動団体に対する専門家や研究者の連携としては、 $\lceil 45$ 活動への助言・指導」と「25 具体作業への助言・指導」の 2 通りがある。また、企業や河川管理者、地方自治体等 が行う「49 資金助成」や「48 人材提供」等の支援は、住民活 動を底辺で支える役割を果たす他、22 人員提供」は具体· 実践活動を直接的に支援する。河川管理者や地方自治体 の「47 情報公開・提供」は、住民活動を底辺付近から支援す る役割を果たす。一般住民の関わりとしては、「46 意見発 信」、活動団体に対する「43 諸活動への参画」や「17 保全· 
管理作業への参加」、河川管理者に対する「26 整備計画策 定への参加」や「15 環境修復整備への参加」の他、個人で行 う「12 家庭での配慮」がある。

\section{5. おわりに}

水環境に関わる住民活動について分析し、活動団体の 実態と活動傾向を把握した上で、役割連携の観点から「川 づくり」と「水環境管理」の流域連携の連関構造を明らか にした。また、連携の方途についてその可能性と課題を 指摘した。今後、この流域連携の方途に関する可能性と 課題を、多くの事例の中で実証することが必要であるが、 各地で手探り状態の水環境保全における流域連携の取組 みに対し、有益な知見と方途の一端を示すことができた と考える。得られた主な結果を以下に示す。

(1)活動団体数は都道府県人口に比例し、その設立は水環 境問題の進行と行政の取組みに呼応することを示した。 (2)活動団体は小規模で地域に密着した活動が多く、流域 規模での取組みには連携が不可欠であることを示した。 (3)流域連携のための水環境に関わる活動(役割)を11の大 分類、35 の中分類、 100 の小分類に分類·整理した。

(4)活動の傾向は、「野外実践一室内」「水質浄化一生物保 全」「対外一自主」「「動的一静的」「発信一対話·交流」の 5 軸で説明でき、その傾向から活動団体を 7 タイプに類型 化した。近年は水質净化単独や清掃·美化単独のタイプは 減少し、生物保全系で多様な活動を展開する団体が多い。 (5)「づくり」と「水環境管理」に関する諸活動の連関を ISM 法により構造化し、活動団体、河川管理者、地方自治 体、専門家、企業、一般住民の役割連携の構造を明らか にし、段階的な役割連携の有効性を示した。

(6)「川づくり」と「水環境管理」に関する住民活動の流域連 携の可能性と課題として、調査·研究的な活動の広域化、 提案·対話型の活動のネットワーク化と能力向上、市民プ ラン策定の導入、学習·交流機会の拡大、専門家の参画、
一般住民の参加促進等が重要であること等を指摘した。

最後に、本研究の基礎的なデー夕の集計·整理において 鳥取大学工学部の学生であった河毛孝斗君の協力を得た ことを記し、謝意を表わす。

\section{参考文献}

1 ) 水環境ビジョン懇談会 : 失われた「水と人との関係」の回復 と新たな展開を目指して〜今後の水環境保全のあり方〜， 1995.

2 ) 例えば、全国水環境交流会 : 第 7 回全国水睘境シンポ\&交流 会 in Tokyo 予稿集, 全国水環境交流会, 1999.

3 ) 水環境学会編 : 国内環境保全活動方策に関する調査一水環境 活動編一, 噮境事業団, 1995 .

4) 小浜明・江成敬次郎：河川流域の特徵が住民の河川に対する 意識に与える影響〜近傍法によるアンケート自由記述分の 分析〜，環境システム研究，vol. 22, pp9-14, 1994.

5 ) 宮本善和·道上正規·喜多秀行·檜谷治 : 身近な川に対する流 域住民の関心度の向上之参加意向に関する研究, 水工学論文 集, 第 44 巻, 2000.

6 ) 上月康則·村上仁士·山中英夫·多田清富·和田智行 : 流域住民 連携による「清流」河川の環境保全に関する考察，環境システ 厶研究, vol. 27, pp. 69-80, 1999 .

7 ) 流域交流䬶談会: パートナーシップではじめるくいい川つつくく り, 流域交流䈍談会, 1996.

8 ）財) 日本環境協会編：平成 10 年度版環境N GO総覧, (財) 日本環境協会 1998 .

9 ) 椹木義一・河村和彦編 : 参加型システムズ・アプローチー手法 と応用, 日刊工業新聞社, 1981 .

10) 吉川勝秀 : 地域づくりにおける川、流域への着目一地域の素材 としての川、まとまりのある単位としての流域一,「山国川 新たなる 流域連携に向けて」, 豊前の国建設俱楽部, pp3-44, 1999.

11)(財)リバーフロント整備センター:ふるさとの川をつくり育てる, 大 成出版, 2000.

12)環境庁水質保全局:日本の水環境行政, 1998.

13) 小倉紀雄: 身近な水を調べる市民による環境監視ネットワー クの重要性, 家庭科学, pp11-18, 1991 .

14) 新河岸川水系水環境連絡会: 身近な川の一斉調査報告書, 新 河岸川水系水環境連絡会, 1999 .

15）宮本善和 : 住民活動を通した川づくり関連情報の収集に関す る一考察, 土木学会第 53 回年次学術講演会講演集 VII, pp370-371, 1998.

16) 廣野吉幸·清野聡子·堂前雅史 : 生態工学は河川を救えるか 科学/技術と社会との新たな関係を求めて, 科学, VOL. 69 N0. 3 MAR., 岩波書店, 1999 .

17）大澤浩一:鶴見川流域ネットワーキング の流域活動とそのしく み, 河川, 1999-5 月号, pp. 33-38, (社) 日本河川協会, 1999

18) 例えば、新河岸川流域総合治水対策協議会 : 新河岸川フオー ラム'99 記録集, 流域総合治水対策協議会, 1999.

\section{水環境に関連する住民活動の実態分析と流域連携に関する考察*}

宮本善和 $* * \cdot$ 道上正規 $* * * \cdot$ 喜多秀行 $* * * * \cdot$ 檜谷治 $* * * * *$

本研究は、流域連携による水環境保全のあり方を見出すため、まず水環境に関連する住民活動の実態を既存統計資 料の整理·分析から把握した。そして、確認された活動内容から、数量化理論 3 類とクラスター分析で活動の傾向を分 析するとともに団体を 7 タイプに類型化した。次に、流域連携のテーマとして「川づくり」と「水環境管理」の $2 つ$ を設定し、役割連携の観点からこれらに関連する諸活動を ISM 法で構造化し、考察を行った。その結果、活動団休、 河川管理者、地方自治体、専門家、企業、一般住民の役割の構造が明確になり、段階的な役割連携の有効性が明らか となった。また、流域連携を促すための課題点と対処の方向性について言及した。

\section{Citizen Activity for Preservation of Water Environment and Cooperation in the Basin*}

Yoshikazu Miyamoto** $^{* *}$ Masanori Michiue ${ }^{* * *} \cdot$ Hideyuki Kita $^{* * *} \cdot$ Osamu Hinokidani ${ }^{* * * * *}$

This paper has understood the contents of citizen activity for preservation of a water environment first. Secondary, by using Quantification theory type 3 and Cluster analysis, the tendency of activity and 7 types classification about the group have been confirmed. And then, it has structured various activities by method of ISM. As a result, the relation of role between the activity group, river manager, local governments, experts and company and general residents has become clear, and validity of hierarchical cooperation has understood. Also, it has shown the directions of some problems and enforcement which stimulates cooperation. 